\title{
Aortic Stenosis From the Perspective of the Current Guidelines
}

\author{
Marko Mornar Jelavic ${ }^{1,2}$ (D), Hrvoje Pintaric ${ }^{2,3}$ \\ ${ }^{1}$ Institute for Cardiovascular Prevention and Rehabilitation, Zagreb, Croatia \\ ${ }^{2}$ School of Dental Medicine, University of Zagreb, Zagreb, Croatia \\ ${ }^{3}$ Department of Emergency Medicine, Clinic for Internal Medicine, University Hospital Center "Sestre milosrdnice", Zagreb, \\ Croatia
}

OPEN ACCESS

Correspondence: Marko Mornar Jelavic, MD, PhD mjelavic@yahoo.com orcid.orcid.org/0000-0002-9135-1820

This article was submitted to RAD CASA- Medical Sciences as the review article

Conflict of Interest Statement: The authors declare that the research was conducted in the absence of any commercial or financial relationships that could be construed as a potential conflict of interest.

Received: 6 June 2019 Accepted: 24 June 2019 Published: 22 July 2019

Citation:

Mornar Jelavic and Pintaric. Aortic Stenosis From the Perspective of the

Current Guidelines. RAD CASA: Medical Sciences.

$537=46-47$ (2019): 37-43

DOI: $10.21857 /$ yq32oh40d9

Copyright (C) 2019 Mornar Jelavic and Pintaric. This is an open-access article distributed under the terms of the Creative Commons Attribution License (CC BY). The use, distribution or reproduction in other forums is permitted provided the original author(s) mitted, provided the original author(s) and the copyright owners( $s$ ) are credited and that the original publication in this journal is cited, in accordance whit accepted adacemic practice. No

use, distribution or reproduction is permitted which does not comply with

\begin{abstract}
:
Aortic stenosis (AS) is one of the most common valvular diseases encountered in clinical practice. It is most frequently caused by degenerative aortic valve fibrosis and calcification, and in a lesser number of cases by the calcification of congenital deformed aortic valve (bicuspid); it may occasionally develop after rheumatic fever.

Valve fibrosis and calcification lead to progressive valve restriction, obstruction and increased afterload with left ventricle remodelling for normalization of wall tension and cardiac output. During time, such hypertrophic and fibrotic myocardium deteriorates, resulting in heart failure. Generally, current guidelines of the European Society of Cardiology (ESC) recommend aortic valve replacement (AVR) when the aortic valve is severely stenotic and the patient is symptomatic. Most asymptomatic patients with severe AS should be managed conservatively, except for those with systolic LV dysfunction, an abnormal exercise test, very severe aortic stenosis, severe valve calcification, markedly elevated cardiac biomarkers, and severe pulmonary hypertension without other explanation.

This article will review our current understanding of the pathophysiology of AS and provide detailed information about clinical presentation, diagnostic procedures, disease course, and different treatment strategies for various groups of these patients.
\end{abstract}

KEYWORDS: aortic stenosis, aortic valve replacement, transcatheter aortic valve implantation.

\section{SAŽETAK:}

Stenoza aorte (AS) jedna je od najčešćih bolesti srčanih valvulau kliničkoj praksi. Najčešće je uzrokovana degenerativnom fibrozom aortnih zalistaka i kalcifikacijom, dok su rjeđi razlozi kongenitalno deformirane zalisci aorte (bikuspidalni) ili posljedice reumatske groznice.

Fibroza i kalcifikacija valvula dovode do progresivnog ograničenja, opstrukcije i povećanog after-loada koje dovodi do remodeliranja lijeve klijetke kako bi se kompenzirala napetost zida i ejekcijska frakcija. Tijekom tog vremena, takav hipertrofični i fibrotični miokardij se pogoršava, što dovodi do zatajenja srca. Općenito, sadašnje smjernice Europskog kardiološkog društva (ESC) ukazuju na zamjenu aortnih valvula (AVR) kada je ona ozbiljno stenotična i pacijent je simptomatičan. Većini asimptomatskih bolesnika s teškom AS treba upravljati konzervativno, osim onih s disfunkcijom sistolne LV, abnormalnim testom napora, teškom aortnom stenozom, teškom kalcifikacijom valvula, izrazito povišenim srčanim biomarkerima i teškom plućnom hipertenzijom bez daljnjeg objašnjenja. Ovaj članak će se prikazati pregled i naše sadašnje razumijevanje patofiziologije AS-a i te će pružiti detaljne informacije o kliničkoj slici, dijagnostičkim postupcima, tijeku bolesti i različitim strategijama liječenja za različite skupine bolesnika sa aortnom stenozom.

KLJUČNE RIJEČI: aortna stenoza, zamjena aortnih zalistaka, transkatetersna implantacija valvula 


\section{INTRODUCTION}

Calcific aortic stenosis (AS) is present at around $2 \%$ and $12 \%$ of patients aged $\geq 65$ and $\geq 75$ years, respectively (1-6). In the last group, severe aortic stenosis is present at $3.4 \%$ of patients. With the aging of the population, the number of individuals with AS is expected to increase twofold to threefold in developed countries in the coming decades ${ }^{1-6}$.

Valvular AS may be a consequence of superimposed calcification of congenital bicuspid valve, normal trileaflet valve and rheumatic diseased valve. Also, it is important to evaluate possible obstruction of left ventricular (LV) outflow which may occur above the valve (supravalvular stenosis) or below the valve (discrete subvalvular stenosis). Finally, hypertrophic cardiomyopathy may cause subaortic obstruction ${ }^{1,2}$.

Calcific (formerly "senile" or "degenerative") aortic valve disease, affecting a congenital bicuspid or normal trileaflet valve, is now the most common cause of AS in adults ${ }^{1,2}$. It may be a consequence of normal degenerative process as well as due to influence of atherosclerotic promoting factors, i.e. dyslipidemia, hyperglycemia, arterial hypertension, smoking, obesity, etc ${ }^{1-11}$. It is important to emphasize that aortic sclerosis, even in the absence of valve obstruction or known cardiovascular disease, is associated with an increased risk of myocardial infarction (MI) and cardiovascular and all-cause mortality ${ }^{2,5}$.

\section{Pathophysiology of Aortic Stenosis}

Due to chronic valve obstruction and increased afterload, the ventricle typically undergoes hypertrophic remodeling (concentric remodeling, concentric hypertrophy, or eccentric hypertrophy) characterized by myocyte hypertrophy and increased wall thickness. It reduces wall stress (afterload) and maintains LV ejection performance. But, increased or maladaptive (insufficient) LV remodeling may be associated with more severe ventricular dysfunction and heart failure (HF) symptoms, as well as higher mortality ${ }^{13-15}$.

Hypertrophic remodeling also impairs diastolic myocardial relaxation and increases stiffness ${ }^{16,17}$, as modulated by cardiovascular and metabolic comorbidities ${ }^{18}$. Higher cardiomyocyte stiffness, increased myocardial fibrosis as a part of hypertrophic remodeling process, advanced-glycation end products, and metabolic abnormalities each contribute to increased chamber stiffness and higher end-diastolic pressures ${ }^{16}$. Increased chamber pressures, especially during diastole, leads to pulmonary hypertension in many patients with AS. The hypertrophied left ventricle, increased systolic pressure and prolongation of ejection increases myocardial oxygen consumption. Patients with AS may have normal epicardial coronary arteries, but decreased myocardial capillary density in the hypertrophied ventricle, increased LV end-diastolic pressure, and a shortened diastole decreases the coronary perfusion pressure gradient and myocardial blood flow. It creates an imbalance between myocardial oxygen supply and demand, especially in the subendocardium ${ }^{1,2,16-18}$.

\section{Clinical Presentation}

Most patients presents with systolic murmur on physical examination, with confirmation of the diagnosis by echocardiography. The most common clinical presentation is a gradual decrease in exercise tolerance, fatigue, or dyspnea on exertion, due to LV diastolic dysfunction, elevated end-diastolic pressure and pulmonary congestion ${ }^{1,2,19,20}$. Also, exertional symptoms may be a consequence of the limited ability to increase cardiac output with exercise. More severe exertional dyspnea, with orthopnea, paroxysmal nocturnal dyspnea, and pulmonary edema, reflects various degrees of pulmonary venous hypertension ${ }^{1,2}$.

Angina during exertion is a frequent symptom, caused with imbalance of increased oxygen needs in hypertrophied myocardium and decreased delivery secondary to the excessive compression of coronary vessels. Syncope most often is caused by inadequate increase in cardiac output related to valvular stenosis, systemic vasodilatation during exertion and consequent brain hypoperfu$\operatorname{sion}^{1,2}$.

\section{DiAgnOSIS}

\section{Physical findings}

The specific finding with severe AS is a slow-rising, late-peaking and low-amplitude carotid impulse (parvus and tardus) ${ }^{2}$. The ejection systolic murmur of AS typically is heard best at the base of the heart and radiation to the neck. It may become softer with failing ventricle. Splitting of second heart sound (S2) implies the aortic valve leaflets are flexible enough for creating an audible closing sound (A2). The intensity of the systolic murmur varies according to the duration of diastole (atrial fibrillation, premature beats). It is augmented by squatting, which increases stroke volume, and reduced during the strain of the Valsalva maneuver and standing due to the reduction of transvalvular flow ${ }^{2}$.

\section{Diagnostic testing}

Echocardiography It is the standard approach for evaluating and following patients with AS and selecting them for operation. According to the guidelines ${ }^{1,2,21}$, valve obstruction to LV outflow is graded as:

1) mild obstruction: aortic jet velocity of $2.0-2.9 \mathrm{~m} / \mathrm{sec}$, mean gradient $\leq 20 \mathrm{~mm} \mathrm{Hg}$, aortic valve area (AVA) $1.5-2.0 \mathrm{~cm}^{2}$; 2) moderate obstruction: aortic jet velocity of $3.0-3.9 \mathrm{~m} / \mathrm{sec}$, mean gradient 20 - $39 \mathrm{~mm} \mathrm{Hg}$, AVA $1.0-1.5 \mathrm{~cm}^{2}$; and 3) severe obstruction: aortic jet velocity of $\geq 4 \mathrm{~m} / \mathrm{sec}$, mean gradient $\geq 40 \mathrm{~mm} \mathrm{Hg}$, AVA $\leq 1.0 \mathrm{~cm}^{2}$.

Furthermore, four categories of aortic stenosis can be defined $^{1,2,21}$ :

a) High-gradient AS (valve area $<1.0 \mathrm{~cm}^{2}$, mean gradient $>40 \mathrm{mmHg}$ ). Severe aortic stenosis can be assumed irrespective of whether LVEF and flow are normal or reduced.

b) Low-flow, low-gradient AS with reduced ejection fraction [valve area $<1.0 \mathrm{~cm}^{2}$, mean gradient $<40 \mathrm{mmHg}$, ejection fraction $<50 \%$, stroke volume index $(\mathrm{SVi})<35 \mathrm{~mL} / \mathrm{m} 2]$. There is 
LV dysfunction with reduced blood flow (SVI $<35 \mathrm{~mL} / \mathrm{m} 2)$. In this situation, dobutamine stress echocardiography (DSE) can help to distinguish between pseudo-severe and true severe AS. More precisely, DSE may allow iden-tification of the presence or absence of contractile reserve (flow reserve), which is defined as an increase in stroke volume $\geq 20 \%$ on dobutamine. In the absence of contractile reserve, no solid conclusions can be drawn with regard to severity of AS. In contrast, in the presence of a contractile reserve, differential diag $\neg$ nosis between true severe and pseudo-severe AS (reduced valve opening due to primary myocardial disease and limited contractile driving forces) may be possible. In true severe AS, a significant increase in transaortic gradients with increasing flow is observed whereas the calculated valve area remains small (e.g. mean gradient $>40$ mmHg and AVA $<1.0-1.2 \mathrm{~cm}^{2}$ at peak stress). In pseudo-severe AS, gradients typically remain low, while the calculated valve area increases (e.g. mean gradient $<30-40 \mathrm{mmHg}$ and AVA $>$ $1.0-1.2 \mathrm{~cm}^{2}$ at peak stress).

c) Low-flow, low-gradient AS with preserved ejection fraction [valve area $<1.0 \mathrm{~cm}^{2}$, mean gradient $<40 \mathrm{mmHg}$, ejection fraction $>50 \%, \mathrm{SVi}<35 \mathrm{~mL} / \mathrm{m} 2$ ]. This is typically encountered in the elderly and is associated with small ventricular size, marked LV hypertrophy and frequently a history of hypertension.

The diagnosis of severe aortic stenosis in this setting remains challenging and includes positive clinical criteria (typical symptoms without other explanation, elderly patient ( $>70$ years)), qualitative imaging data (LV hypertrophy and reduced LV longitudinal function without other explanation) and quantitative imaging data (mean gradient 30-40 mmHg, AVA $\leq 0.8 \mathrm{~cm}^{2}$, low flow (SVI $<35 \mathrm{~mL} / \mathrm{m} 2$ ). Finally, the degree of valve calcification by MSCT is related to aortic stenosis severity and outcome. Its assessment has therefore gained increasing importance in this setting.

d) Normal-flow, low-gradient AS with preserved ejection fraction [valve area $<1.0 \mathrm{~cm}^{2}$, mean gradient $<40 \mathrm{mmHg}$, ejection fraction $\geq 50 \%, \mathrm{SVi}>35 \mathrm{~mL} / \mathrm{m} 2$ ]. These patients will in general have only moderate aortic stenosis.

Finally, valve area may be $\geq 1.0 \mathrm{~cm}^{2}$ with a peak velocity higher than $4 \mathrm{~m} / \mathrm{s}$ and mean gradient $\geq 40 \mathrm{mmHg}$ in the pres $\neg$ ence of a high transvalvular flow. This may be due to concomitant AR or shunt lesions. Although valve area may not indicate severe AS, haemodynamics remain consistent with severe LV pressure overload and therefore severe aortic valve disease. For clinical decision-making, reversible causes of increased flow in case of high cardiac output (fever, anaemia, hyperthyroidism, etc.) must be excluded.

Exercise stress testing. It may be used in apparently asymptomatic patients to unmask symptoms or demonstrate limited exercise capacity or an abnormal blood pressure response ${ }^{1,2}$. It should be absolutely avoided in symptomatic patients.

Computed tomography (CT). It may be used in cases with sus- pected aortic root disease, especially at patients with a bicuspid valve. Evaluation of aortic dimensions at several levels is necessary for clinical decision making and surgical planning. Also, CT may be helpful when the severity of the stenosis is in doubt, particularly in those with low-flow, low-gradient $\mathrm{AS}^{1,2}$.

Cardiac catheterization. It is now recommended only when noninvasive tests are inconclusive, when clinical and echocardiographic findings are discrepant, and for coronary angiography before surgical intervention ${ }^{1,2}$.

Cardiac magnetic resonance (CMR). It is useful for evaluation of LV volume, function, and mass ${ }^{1,2}$. CMR is used in assessing aortic dimensions in patients with a bicuspid valve. It is also practical for assesing myocardial fibrosis and can be used instead of CT for evaluation of valve morphology, vascular anatomy, and annular dimensions in preparation for transcatheter aortic valve replacement. But, it should be avoided in assessment of transvalvular velocities.

\section{Disease Course \\ Asymptomatic patients}

The rate of progression of AS is highly variable and difficult to predict. The factors associated with more rapid hemodynamic progression included older age, more severe leaflet calcification, renal insufficiency, hypertension, obesity, metabolic syndrome, smoking and hyperlipidemia ${ }^{1,2,6,8,9}$.

Asymptomatic patients with moderate to severe AS have excellent prognosis ${ }^{1,2,22}$. Several predictors of symptoms onset at patients with asymptomatic severe AS are abnormal exercise test, elevated BNP, moderate to severe valve calcification, very high aortic velocity ( $>5$ or $5.5 \mathrm{~m} / \mathrm{sec}$ ), rapid increase in aortic velocity, increased hypertrophic LV remodeling, reduced LV longitudinal systolic strain, myocardial fibrosis and pulmonary hypertension. The strongest predictor of progression to symptoms is the Doppler aortic jet velocity ${ }^{1,2,19,21,23,24}$.

Exercise testing monitored by a physician should be applied in adults with severe AS when symptom status is unclear, and patients who develop symptoms or exhibit a decrease in blood pressure with exertion should be considered to have symptomatic disease. An elevated BNP level may be helpful when symptoms are equivocal or when stenosis severity is only moderate, but the role of BNP monitoring in the evaluation of disease progression has not been fully defined ${ }^{1,2}$.

Generally, repeat echocardiographic imaging is performed every 6 to 12 months for severe AS, every 1 to 2 years for moderate AS, and every 3 to 5 years for mild AS, unless a change in signs or symptoms prompts repeat imaging sooner ${ }^{1,2}$.

\section{Symptomatic patients}

Once even mild symptoms are present, survival is poor unless outflow obstruction is relieved. The average survival without aortic valve replacement (AVR) is only 1 to 3 years after 
symptom onset ${ }^{1,2,25-28}$. Also, the outlook is poorest when the left ventricle has failed and the cardiac output and transvalvular gradient are both low. The risk of sudden death is high with symptomatic severe AS, so these patients should be promptly referred for AVR. In patients who do not undergo AVR, recurrent hospitalizations for angina and decompensated heart failure are common, associated with significant consumption of health care resources ${ }^{1,2,25-28}$.

\section{TREATMENT}

Studies revealed that medical treatment has no influence on disease progression and aortic valve replacement (AVR) is superior to medical therapy at patients with severe symptomatic AS 1,2,29-61. It is of mutual importance that patients report promptly the development of any symptoms possibly related to AS as the risk of sudden death increases dramatically once symptoms are present. In asymptomatic patients with AS of any degree, evaluation and treatment for conventional cardiovascular risk factors is recommended in accordance with established guidelines. Hypertension treatment reduces ventricular afterload and hypetrophic LV remodeling. Also, vasodilation is accompanied by increases in stroke volume, even in patients with severe $\mathrm{AS}^{1,2}$. Because the renin-angiotensin system is upregulated in the valve and ventricle of patients with AS, angiotensin-converting-enzyme (ACE) inhibitors or angiotensin receptor blockers (ARBs) may preferentially considered ${ }^{1,2}$.

Coronary artery disease and statin prescribtion should be guided according to the primary and secondary preventio guidelines and not be infleunced by the presence of $\mathrm{AS}^{1,2}$.

Atrial fibrillation (AF) or atrial flutter are frequent at patients with AS, especially with concomitatnt mitral valve disease. As the loss of the left atrial „buster pump“ during AF affects LV filling and may cause sudden fall in cardiac output and serious hypotension, clinicans must choose between the two treatment strategies, rate and rhytm control. In patients with chronic stable HF diuretics may reduce congestion and provide some symptomatic relief prior to valve replacement. Patients with acute decompensated HF may benefit from medical therapy as a bridge to definitive therapy with valve replacement. Nitroprusside has been used during hemodynamic monitoring in the intensive care unit to unload the left heart, reduce congestion, and improve forward flow. Similarly, phosphodiesterase type 5 inhibition has been shown to provide acute improvements in pulmonary and systemic hemodynamics resulting in biventricular unloading ${ }^{1,2}$. These medications may improve the patient's hemodynamic status, allowing the AVR procedure to be performed more safely.

\section{Symptomatic severe aortic stenosis}

Intervention is indicated ${ }^{1,2}$ in symptomatic patients with severe, high-gradient aortic stenosis (mean gradient $\geq 40 \mathrm{mmHg}$ or peak velocity $\geq 4.0 \mathrm{~m} / \mathrm{s}$ ) (Class I, Level B).
Intervention is indicated in symptomatic patients with severe low-flow, low-gradient $(<40 \mathrm{mmHg})$ aortic stenosis with reduced ejection fraction and evidence of flow (contractile) reserve excluding pseudosevere aortic stenosis (Class I, Level C). Intervention should be considered in symptomatic patients with low-flow, low-gradient $(<40 \mathrm{mmHg})$ aortic stenosis with normal ejection fraction after careful confirmation of severe aortic stenosis (Class IIa, Level C).

Intervention should be considered in symptomatic patients with low-flow, low-gradient aortic stenosis and reduced ejection fraction without flow (contractile) reserve, particularly when CT calcium scoring confirms severe aortic stenosis (Class IIa, Level C).

\section{Choice of intervention in symptomatic severe aortic stenosis}

Surgical aortic valve replacement (SAVR) is recommended $(1,2)$ in patients at low surgical risk and no other risk factors (frailty, porcelain aorta, sequelae of chest radiation, older age, previous cardiac surgery, chest deformations, etc) (Class I, Level C). Transcatheter aortic valve implantation (TAVI) is recommended in patients who are not suitable for SAVR as assessed by the Heart Team (Class I, Level B). It offers a less invasive option for the treatment of severe AS, with evidence supporting TAVI compared with medical therapy in inoperable patients and superior with surgical aortic valve replacement (SAVR) in high-risk patients.

Balloon aortic valvotomy (BAV) may be considered as a bridge to SAVR or TAVI in haemodynamically unstable patients or in patients with symptomatic severe aortic stenosis who require urgent major non-cardiac surgery (Class IIb, Level C). BAV may be considered as a diagnostic means in patients with severe aortic stenosis or other potential causes for symptoms (i.e. lung disease) and in patients with severe myocardial dysfunction, pre-renal insufficiency or other organ dysfunction that may be reversible with balloon aortic valvotomy when performed in centres that can escalate to TAVI (Class IIb, Level C).

\section{Asymptopmatic severe aortic stenosis}

SAVR is indicated ${ }^{1,2}$ in asymptomatic patients with severe aortic stenosis and systolic LV dysfunction (LVEF <50\%) not due to another cause (Class I, Level C).

SAVR is indicated in asymptomatic patients with severe aortic stenosis and an abnormal exercise test showing symptoms on exercise clearly related to aortic stenosis (Class I, Level C). SAVR should be considered in asymptomatic patients with severe aortic stenosis and an abnormal exercise test showing a decrease in blood pressure below baseline (Class IIa, Level C).

SAVR should be considered in asymptomatic patients with normal ejection fraction and none of the above-mentioned exercise test abnormalities if the surgical risk is low and one of the following findings is present (Class IIa, Level C): 
- Very severe aortic stenosis defined by a $V \max >5.5 \mathrm{~m} / \mathrm{s}$

- Severe valve calcification and a rate of Vmax progression $\geq 0.3 \mathrm{~m} / \mathrm{s} /$ year

- Markedly elevated BNP levels ( >threefold age- and sex-corrected normal range) confirmed by repeated measurements without other explanations

- Severe pulmonary hypertension (systolic pulmonary artery pressure at rest $>60 \mathrm{mmHg}$ confirmed by invasive measurement) without other explanation.

\section{Other indications for intervention}

SAVR is indicated ${ }^{1,2}$ in patients with severe aortic stenosis undergoing CABG or surgery of the ascending aorta or of another valve (Class I, Level C).

SAVR should be considered in patients with moderate aortic stenosis undergoing CABG or surgery of the ascending aorta or of another valve after Heart Team decision (Class IIa, Level C).

\section{CONCLUSION}

Severe AS is the most common form of valve heart disease. AVR is primary recommended when the aortic valve is severely stenotic and the patient is symptomatic. Most asymptomatic patients with severe AS should be managed conservatively, with close monitoring to detect new onset of symptoms, except those with systolic LV dysfunction, an abnormal exercise test, very severe aortic stenosis, severe valve calcification, markedly elevated cardiac biomarkers and severe pulmonary hypertension without other explanation. TAVI offers a less invasive option for the treatment of severe AS, with evidence supporting TAVI compared with medical therapy in inoperable patients and superior with SAVR in high-risk patients.

\section{AUTHOR CONTRIBUTIONS:}

All authors listed have made a substantial, direct and intellectual contribution to the work, and approved it for publication.

\section{LITERATURE:}

1. Falk V, Baumgartner H, Bax JJ, De Bonis M, Hamm C, Holm PJ, et al. 2017 ESC/EACTS Guidelines for the management of valvular heart disease. Eur J Cardiothorac Surg. 2017;52:616-64.

2. Zipes PD, Libby P, Bonow OR, eds. Braunwald's Heart Disease: A Textbook of Cardiovascular Medicine. 11th ed. Philadelphia: Elsevier, 2019.

3. D’Arcy JL, Coffey S, Loudon MA, Kennedy A, Pearson-Stuttard J, Birks J, et al. Large-scale community echocardiographic screening reveals a major burden of undiagnosed valvular heart disease in older people: the OxVALVE Population Cohort Study. Eur Heart J. 2016;37:3515-22.

4. Osnabrugge RL, Mylotte D, Head SJ, Van Mieghem NM, Nkomo VT, LeReun CM, et al. Aortic stenosis in the elderly: disease prevalence and number of candidates for transcatheter aortic valve replacement: a meta-analysis and modeling study. J Am Coll Cardiol. 2013;62:100212 .

5. Coffey S, Cox B, Williams MJ. The prevalence, incidence, progression, and risks of aortic valve sclerosis: a systematic review and meta-analysis. J Am Coll Cardiol. 2014;63:2852-2861.

6. Lindman BR, Clavel M-A, Mathieu P, Iung B, Lancellotti P, Otto CM, et al. Calcific aortic stenosis. Nat Rev Dis Primers. 2016;2:16006. 7. Kamstrup PR, Tybjaerg-Hansen A, Nordestgaard BG. Elevated lipoprotein(a) and risk of aortic valve stenosis in the general population. J Am Coll Cardiol. 2014;63:470-7.

8. Capoulade R, Chan KL, Yeang C, Mathieu P, Bossé Y, Dumesnil JG, et al. Oxidized phospholipids, lipoprotein(a), and progression of calcific aortic valve stenosis. J Am Coll Cardiol. 2015;66:1236-46.

9. Capoulade R, Mahmut A, Tastet L, Arsenault M, Bédard É, Du-

mesnil JG, et al. Impact of plasma Lp-PLA2 activity on the progression of aortic stenosis: the PROGRESSA study. JACC Cardiovasc Imaging. 2015;8:26-33.

10. Mahmut A, Boulanger MC, El Husseini D, Fournier D, Bouchareb R, Després JP, et al. Elevated expression of lipoprotein-associated phospholipase A2 in calcific aortic valve disease: implications for valve mineralization. J Am Coll Cardiol. 2014;63:460-9.

11. Bouchareb R, Mahmut A, Nsaibia MJ, Boulanger MC, Dahou A, Lépine JL, et al. Autotaxin derived from lipoprotein(a) and valve interstitial cells promotes inflammation and mineralization of the aortic valve. Circulation. 2015;132:677-90.

12. Rogers MA, Aikawa E. A not-so-little role for lipoprotein(a) in the development of calcific aortic valve disease. Circulation. 2015;132:621-3. 13. Duncan AI, Lowe BS, Garcia MJ, Xu M, Gillinov AM, Mihaljevic $\mathrm{T}$, et al. Influence of concentric left ventricular remodeling on early mortality after aortic valve replacement. Ann Thorac Surg. 2008;85:2030-9.

14. Mihaljevic T, Nowicki ER, Rajeswaran J, Blackstone EH, Lagazzi L, Thomas J, et al. Survival after valve replacement for aortic stenosis: implications for decision making. J Thorac Cardiovasc Surg. 2008;135:1270-8.

15. Beach JM, Mihaljevic T, Rajeswaran J, Marwick T, Edwards ST, Nowicki ER, et al. Ventricular hypertrophy and left atrial dilatation persist and are associated with reduced survival after valve replacement for aortic stenosis. J Thorac Cardiovasc Surg. 2014;147:362-9.e8.

16. Falcao-Pires I, Hamdani N, Borbely A, Gavina C, Schalkwijk CG, van der Velden

J, et al. Diabetes mellitus worsens diastolic left ventricular dysfunction in aortic stenosis through altered myocardial structure and cardiomyocyte stiffness. Circulation. 2011;124:1151-9.

17. Falcao-Pires I, Palladini G, Goncalves N, van der Velden J, Moreira-Gonçalves 
D, Miranda-Silva D, et al. Distinct mechanisms for diastolic dysfunction in diabetes mellitus and chronic pressure-overload. Basic Res Cardiol. 2011;106:801-14.

18. Page A, Dumesnil JG, Clavel MA, Chan KL, Teo KK, Tam JW, et al. Metabolic syndrome is associated with more pronounced impairment of left ventricle geometry and function in patients with calcific aortic stenosis: a substudy of the ASTRONOMER (Aortic Stenosis Progression Observation Measuring Effects of Rosuvastatin). J Am Coll Cardiol. 2010;55:1867-74.

19. Lindman BR, Bonow RO, Otto CM. Current management of calcific aortic stenosis. Circ Res. 2013;113:223-237.

20. Carabello BA, Paulus WJ. Aortic stenosis. Lancet. 2009;373:956-966. 21. Lancelloti P, Zamorano LJ, Habib G, eds. The EACVI Textbook of Echocardiography. 2nd ed. New York: Oxford University Press, 2017. 22. Dal Bianco JP, Khandheria BK, Mookadam F, Gentile F, Sengupta PP. Management of asymptomatic severe aortic stenosis. J Am Coll Cardiol. 2008;52:1279-92.

23. Stewart RA, Kerr AJ, Whalley GA, Legget ME, Zeng I, Williams MJ, et al. Left ventricular systolic and diastolic function assessed by tissue Doppler imaging and outcome in asymptomatic aortic stenosis. Eur Heart J. 2010;31:2216-22.

24. Capoulade R, Le Ven F, Clavel MA. Echocardiographic predictors of outcomes in adults with aortic stenosis. Heart. 2016;102:934-942. 25. Bach DS, Siao D, Girard SE, Duvernoy C, McCallister BD Jr, Gualano SK. Evaluation of patients with severe symptomatic aortic stenosis who do not undergo aortic valve replacement: the potential role of subjectively overestimated operative risk. Circ Cardiovasc Qual Outcomes. 2009;2:533-9.

26. Leon MB, Smith CR, Mack M, Miller DC, Moses JW, Svensson LG, et al. Transcatheter aortic-valve implantation for aortic stenosis in patients who cannot undergo surgery. N Engl J Med. 2010;363:1597-607. 27. Makkar RR, Fontana GP, Jilaihawi H, Kapadia S, Pichard AD, Douglas PS, et al. Transcatheter aortic-valve replacement for inoperable severe aortic stenosis. N Engl J Med. 2012;366:1696-704.

28. Clark MA, Arnold SV, Duhay FG, Thompson AK, Keyes MJ, Svensson LG,et al. Five-year clinical and economic outcomes among patients with medically managed severe aortic stenosis: results from a Medicare claims analysis. Circ Cardiovasc Qual Outcomes. 2012;5:697-704. 29. Kapadia SR, Leon MB, Makkar RR, Tuzcu EM, Svensson LG, Kodali S, et al. 5-year outcomes of transcatheter aortic valve replacement compared with standard treatment for patients with inoperable aortic stenosis (PARTNER 1): a randomised controlled trial. Lancet. 2015;385:2485-91.

30. Lindman BR, Otto CM. Time to treat hypertension in patients with aortic stenosis. Circulation. 2013;128:1281-3.

31. Dweck MR, Boon NA, Newby DE. Calcific aortic stenosis: a disease of the valve and the myocardium. J Am Coll Cardiol. 2012;60:1854-63. 32. Burup Kristensen C, Jensen JS, Carstensen HG, Mogelvang R. Atrial fibrillation in aortic stenosis: echocardiographic assessment and prognostic importance. Cardiovasc Ultrasound. 2012;10:38.

33. Kapadia S, Stewart WJ, Anderson WN, Babaliaros V, Feldman T, Cohen DJ, et al. Outcomes of inoperable symptomatic aortic stenosis patients not undergoing aortic valve replacement: insight into the impact of balloon aortic valvuloplasty from the PARTNER trial (Placement of AoRtic TraNscathetER Valve trial). JACC Cardiovasc Interv. 2015;8:324-33.

34. Kapadia SR, Goel SS, Yuksel U, Agarwal S, Pettersson G, Svensson LG, et al. Lessons learned from balloon aortic valvuloplasty experience from the pre-transcatheter aortic valve implantation era. J Interv Cardiol. 2010;23:499-508.

35. Zilberszac R, Gabriel H, Schemper M, Zahler D, Czerny M, Maurer $\mathrm{G}$, et al. Outcome of combined stenotic and regurgitant aortic valve disease. J Am Coll Cardiol. 2013;61:1489-95.

36. Bonow RO, Leon MB, Doshi D, Moat N. Aortic valve disease: current management and future challenges. Lancet. 2016;387:1312-23. 37. Kafa R, Kusunose K, Goodman AL, Svensson LG, Sabik JF, Griffin $\mathrm{BP}$, et al. Association of abnormal postoperative left ventricular global longitudinal strain with outcomes in severe aortic stenosis following aortic valve replacement. JAMA Cardiol. 2016;1:494-6.

38. Brown JM, O’Brien SM, Wu C, Sikora JA, Griffith BP, Gammie JS. Isolated aortic valve replacement in North America comprising 108,687 patients in 10 years: changes in risks, valve types, and outcomes in the Society of Thoracic Surgeons National Database. J Thorac Cardiovasc Surg. 2009; 137:82-90.

39. Shahian DM, O’Brien SM, Filardo G, Ferraris VA, Haan CK, Rich JB, et al. The Society of Thoracic Surgeons 2008 cardiac surgery risk models. Part 3. Valve plus coronary artery bypass grafting surgery. Ann Thorac Surg. 2009;88:S43-S62.

40. O’Brien SM, Shahian DM, Filardo G, Ferraris VA, Haan CK, Rich JB, et al. The Society of Thoracic Surgeons 2008 cardiac surgery risk models. Part 2. Isolated valve surgery. Ann Thorac Surg. 2009;88:S23-S42.

41. Barreto-Filho JA, Wang Y, Dodson JA, Desai MM, Sugeng L, Geirsson $\mathrm{A}$, et al. Trends in aortic valve replacement for elderly patients in the United States, 1999-2011. JAMA. 2013;310:2078-85.

42. Bonow RO. Improving outlook for elderly patients with aortic stenosis. JAMA. 2013;310:2045-7.

43. Wendt D, Osswald BR, Kayser K, Thielmann M, Tossios P, Massoudy P, et al. Society of Thoracic Surgeons score is superior to the EuroSCORE determining mortality in high risk patients undergoing isolated aortic valve replacement. Ann Thorac Surg. 2009;88:468-74.

44. Hannan EL, Wu C, Bennett EV, Carlson RE, Culliford AT, Gold JP, et al. Risk index for predicting in-hospital mortality for cardiac valve surgery. Ann Thorac Surg. 2007;83:921-9.

45. Pedrazzini GB, Masson S, Latini R, Klersy C, Rossi MG, Pasotti $\mathrm{E}$, et al. Comparison of brain natriuretic peptide plasma levels versus logistic EuroSCORE in predicting in-hospital and late postoperative mortality in patients undergoing aortic valve replacement for symptomatic aortic stenosis. Am J Cardiol. 2008;102:749-54.

46. Kolh P, Kerzmann A, Honore C, Comte L, Limet R. Aortic valve surgery in octogenarians: predictive factors for operative and long-term results. Eur J Cardiothorac Surg. 2007;31:600-6. 47. Vahl TP, Kodali SK, Leon MB. Transcatheter aortic valve replacement 2016: a modern-day “Through the Looking-Glass" adventure. J Am Coll Cardiol. 2016;67:1472-87. 
48. Smith CR, Leon MB, Mack MJ, Miller DC, Moses JW, Svensson LG, et al. Transcatheter versus surgical aortic-valve replacement in highrisk patients. N Engl J Med. 2011;364:2187-98.

49. Kodali SK, Williams MR, Smith CR, Svensson LG, Webb JG, Makkar RR, et al. Two-year outcomes after transcatheter or surgical aortic-valve replacement. N Engl J Med. 2012;366:1686-95.

50. Adams DH, Popma JJ, Reardon MJ, Yakubov SJ, Coselli JS, Deeb GM, et al. Transcatheter aortic-valve replacement with a self-expanding prosthesis. N Engl J Med. 2014;370:1790-8.

51. Leon MB, Smith CR, Mack MJ, Makkar RR, Svensson LG, Kodali SK, et al. Transcatheter or surgical aortic-valve replacement in intermediate-risk patients. N Engl J Med. 2016;374:1609-20.

52. Thourani VH, Kodali S, Makkar RR, Herrmann HC, Williams M, Babaliaros V, et al. Transcatheter aortic valve replacement versus surgical valve replacement in intermediate-risk patients: a propensity score analysis. Lancet. 2016;387:2218-25.

53. Reardon MJ, Van Mieghem NM, Popma JJ, Kleiman NS, Søndergaard L, Mumtaz M, et al. Surgical or transcatheter aortic-valve replacement in intermediate-risk patients. N Engl J Med. 2017;376:1321-31. 54. Holmes DR Jr, Mack MJ, Kaul S, Agnihotri A, Alexander KP, Bailey SR, et al. ACCF/AATS/SCAI/STS expert consensus document on transcatheter aortic valve replacement. Developed in collaboration with the American Heart Association, American Society of Echocardiography, European Association for Cardio-Thoracic Surgery, Heart Failure Society of America, Mended Hearts, Society of Cardiovascular Anesthesiologists, Society of Cardiovascular Computed Tomography, and Society for Cardiovascular Magnetic Resonance. J Am Coll Cardiol. 2012;9:1200-1254.
55. Nishimura RA, Otto CM, Bonow RO, Carabello BA, Erwin JP 3rd, Fleisher LA, et al. 2017 AHA/ACC focused update of the 2014 AHA/ ACC guideline for the management of patients with valvular heart disease. J Am Coll Cardiol. 2017;70:252-89.

56. Vandvik PO, Otto CM, Siemieniuk RA, Bagur R, Guyatt GH, Lytvyn L, et al. Transcatheter or surgical aortic valve replacement for patients with severe, symptomatic, aortic stenosis at low to intermediate surgical risk: a clinical practice guideline. BMJ. 2016;354:i5085.

57. Siemieniuk RA, Agoritsas T, Manja V, Devji T, Chang Y, Bala MM,, et al. Transcatheter versus surgical aortic valve replacement in patients with severe aortic stenosis at low and intermediate risk: systematic review and meta-analysis. BMJ. 2016;354:i5130.

58. Foroutan F, Guyatt GH, O'Brien K, Bain E, Stein M, Bhagra S, et al. Prognosis after surgical replacement with a bioprosthetic aortic valve in patients with severe symptomatic aortic stenosis: systematic review of observational studies. BMJ. 2016;354:i5065.

59. Lytvyn L, Guyatt GH, Manja V, Siemieniuk RA, Zhang Y, Agoritsas $T$, et al. Patient values and preferences on transcatheter or surgical aortic valve replacement therapy for aortic stenosis: a systematic review. BMJ Open. 2016;6:e014327.

60. Lindman BR, Alexander KP, O'Gara PT, Afilalo J. Futility, benefit, and transcatheter aortic valve replacement. JACC Cardiovasc Interv. 2014;7:707-16.

61. Arnold SV, Reynolds MR, Lei Y, Magnuson EA, Kirtane AJ, Kodali SK, et al. Predictors of poor outcomes after transcatheter aortic valve replacement: results from the PARTNER (Placement of Aortic Transcatheter Valve) trial. Circulation. 2014;129:2682-2690. 